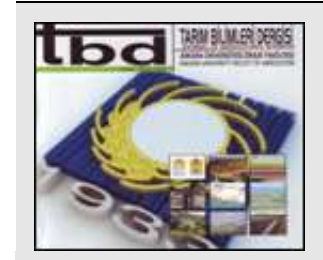

Tarım Bilimleri Dergisi

Journal of Agricultural Sciences

Tar. Bil. Der.

Dergi web sayfası:

www.agri.ankara.edu.tr/dergi

Journal homepage:

www.agri.ankara.edu.tr/journal

\title{
Antioxidant Activity and Total Phenolics of Local Apple Cultivars Encountered along the Coastal Zone of Northeastern Anatolia Region of Turkey*
}

\author{
Said Efe DOST ${ }^{\text {a }}$, Hatice DUMANOĞLU ${ }^{b}$, Ahmet AYGÜN

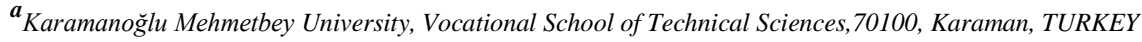

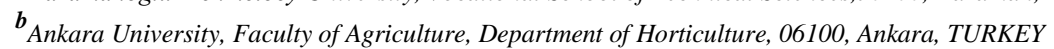 \\ ${ }^{c_{K o c a e l i}}$ University, Faculty of Arts and Science, Department of Biology, 41380, Kocaeli, TURKEY

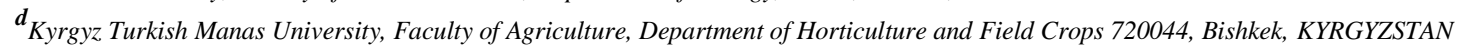 \\ *This paper is a part of $\mathrm{PhD}$ thesis of first author
}

\section{ARTICLE INFO}

Research Article

Corresponding Author: Ahmet AYGÜN, E-mail: ayguna70@yahoo.com, Tel: +9 (0262) 3032162

Received: 26 June 2019, Received in Revised Form: 21 August 2019, Accepted: 29 August 2019

\section{AUTHORS ORCID ID:}

(Said Efe DOST: 0000-0003-4279-7292), (Hatice DUMANOĞLU: 0000-0002-7099-7630), (Ahmet AYGÜN: 0000-0001-7745-3380)

\begin{abstract}
In this study, antioxidant activity and total phenolics in fruit flesh and fruit flesh + skin tissue of local apple cultivars encountered along the coastal zone of Northeastern Anatolia Region (Turkey) and 5 standard cultivars were determined. In local cultivars, antioxidant activities ( $\mu$ mol Trolox equivalent (TE) antioxidant $g$ fresh weight $(\mathrm{fw})^{-1}$ ) varied between $0.17-1.70$ in fruit flesh and between 0.35-1.55 in fruit flesh + skin tissue; in standard cultivars, the values varied between 0.24 ('Royal Gala') and 0.29 ('Granny Smith' and 'Pink Lady') in fruit flesh and between 0.27 ('Jonagold') and 0.61 ('Royal Gala') in fruit flesh + skin tissue. In local cultivars, total phenolics (Gallic acid equivalent (GAE) $\mathrm{kg} \mathrm{fw}^{-1}$ ) varied
\end{abstract}

between 53.26- 00.54 in fruit flesh and between 89.32-406.91 in fruit flesh + skin tissue; the values in standard cultivars varied between 56.30 ('Royal Gala') and 124.64 ('Jonagold') in fruit flesh and between 102.73 ('Summerred') and 198.72 ('Jonagold') in fruit flesh + skin tissue. Present findings revealed that local cultivars generally had 3-4 times greater antioxidant activity and total phenolics than the standard cultivars. Fruit flesh + skin tissue generally had greater antioxidant activity and total phenolics than the fruit flesh alone. However, the local apple cultivar of 'Hemşin Elmas1' had greater values of both parameters in fruit flesh than in fruit flesh + skin tissue.

Keywords: Apple; Trolox; Gallic acid equivalent; Local cultivar

(C) Ankara Üniversitesi Ziraat Fakültesi

\section{Introduction}

For healthy diets, present researches mostly focus on fruits and vegetables rich in phenolics. Phenolic compounds are found in different organs of the plants. They are not nutritious, but play a great role in human health because of their antioxidant characteristics (Margaret et al 2015). Phenolic compounds are structurally composed of simple phenolic molecules bearing one or more hydroxyl groups over an aromatic chain and also cover highly-polymerized components (Balasundram et al 2006; Stratil et al 2007). These compounds are also called as secondary metabolites. They prevent plants from oxidative damages, wounds, pathogen infections and play a role in various physiological processes. Recent epidemiological studies revealed that a diet rich in fruit and vegetables with abundant phenolics recessed the aging process and reduced the risk of cardiovascular diseases, cancer, rheumatoid arthritis, lung diseases, cataracts, Parkinson and Alzheimer diseases (Garcia et al 1997; Middleton et al 2000; Manach et al 2005). Such preventive effects of these compounds are mostly attributed to antioxidative of phytochemicals and vitamins (Szajdek \& Borowska 2008). In general, fruits and vegetables have higher phenolic compounds, thus they have greater effect on both human health and 
country economy. Apple fruits are quite rich in phenolic compounds and have been consumed abundantly since the old ages because of positive health impacts. Today, apple is among the mostly produced and consumed fruit species worldwide. In the U.S.A., about $22 \%$ fruit phenolic compounds are obtained from apple (Vinson et al 2001). Apples are also processed into apple cider, apple juice, and apple puree. Oxy-reduction characteristics allow antioxidant activity of the phenolics to behave like reducing agents, hydrogen donors and singlet oxygen quenchers. Apple phenolics are also used as metal chelating agent (Rice-Evans et al 1995). Phenolic antioxidants of apples are responsible for majority of fruit antioxidant activities (Lee et al 2003). As compared to fruit flesh or seeds, fruit skin has greater amount of phenolic compounds (Wolfe et al 2003; Tsao et al 2005). It was indicated in previous studies that environmental conditions during fruit growth and development significantly influenced phenolic contents and total antioxidant activity in fruit (Imeh \& Khokhar 2002; Lee et al 2003; Vrhovsek et al 2004; Veberic et al 2005). Apples have different phenolic compounds. The quantity and distribution of them vary greatly from one cultivar to another (Khanizadech et al 2008; Bohm et al 2018). Therefore, it is so important to determine phenolics and antioxidant activities of existing and new cultivars.

This study was conducted to determine total phenolics and antioxidant activity of the local apple cultivars prominent with appearance and eating quality in apple genetic sources of Northeastern Anatolia Region of Turkey in comparison with some commercial cultivars.

\section{Material and Methods}

In this study, 50 local apple cultivars originated from the coastal region of Northeastern Anatolia Region in Turkey were used as plant material. Besides, 5 commercial cultivars ('Summerred', 'Royal Gala', 'Jonagold', 'Granny Smith' and 'Pink Lady') were used as controls. Local apple cultivars were summer, autumn or winter types available for fresh consumption. They were selected from a collection orchard established with 250 local apple cultivars on M9 rootstocks in 2010 based on their appearance and eating quality. The orchard has stringed irrigation and drip irrigation systems and the trees are cultivated according to the spindle system. The apple orchard where the study was conducted is located in Ankara province at $848 \mathrm{~m}$ height $39^{\circ} 57^{\prime}$ North latitude and $32^{\circ} 51^{\prime}$ East longitude.

The harvest dates were determined according to fruit color, flesh firmness and soluble solids content. The fruits harvested from local and standard cultivars were washed through distilled water and whole fruit were kept at $-20^{\circ} \mathrm{C}$ in a regular freezer for further analyses of total phenolics and antioxidant activity. Summer, autumn or winter cultivars were kept in these conditions for approximately 4, 2 and 1 month, respectively.

Sample preparation for analyses: 10 fruits were collected from 3 trees for each sample. Fruits were initially thawed at room temperature. Then, $10 \mathrm{~g}$ samples were taken from homogeneously from all 3 sides of the fruit flesh and fruit flesh + skin tissue. They were placed into $50 \mathrm{~mL}$ centrifuge tubes and supplemented with $20 \mathrm{~mL} 80 \%$ acetone. Samples were mixed roughly in a homogenizer for 5 minutes, centrifuged at $+5{ }^{\circ} \mathrm{C}$ and $12000 \mathrm{rpm}$ for 20 minutes and filtered through Whatman Grade 1 filter paper into another tubes. Then, $5 \mathrm{~mL}$ of resultant filtrate was placed into $100 \mathrm{~mL}$ flask and acetone was evaporated by a rotary evaporator at $+40{ }^{\circ} \mathrm{C}$. Following the drying process, samples were supplemented with $5 \mathrm{~mL} 0.01 \%$ hydrochloric acid $\left(\mathrm{HCl}, \mathrm{M}=36.45 \mathrm{~g} \mathrm{~mol}^{-1}\right)$ and manually shaken. For $200 \mathrm{~mL} 0.01 \%$ $\mathrm{HCl}$ solution, $54 \mu \mathrm{L} \mathrm{37 \%} \mathrm{HCl}$ was added to $60 \mathrm{ml}$ distilled water and final volume was completed to $200 \mathrm{~mL}$. Entire liquid in flask was drawn into a syringe, passed through 0.45 micronic filter and placed into two $2.5 \mathrm{ml}$ Eppendorf tubes. The tubes were then preserved at $-20{ }^{\circ} \mathrm{C}$ until further analysis.

Antioxidant activity: Antioxidant activity of the samples was determined in accordance with TEAC (TE Antioxidant Capacity) method (Re et al 1999).

Solutions: $12.25 \mathrm{mM}$ potassium persulphate $\left(\mathrm{K}_{2} \mathrm{O}_{8} \mathrm{~S}_{2}\right)\left(\mathrm{M}=270.32 \mathrm{~g} \mathrm{~mol}^{-1}\right)$ solution; for $100 \mathrm{~mL}$ solution, $0.331 \mathrm{~g}$ $\mathrm{K}_{2} \mathrm{O}_{8} \mathrm{~S}_{2}$ was dissolved in $50 \mathrm{~mL}$ double deionized water $\left(\mathrm{ddH}_{2} \mathrm{O}\right)$ and final volume was completed to $100 \mathrm{~mL}$. ABTS radical solution; for $10 \mathrm{~mL}$ solution, $0.0384 \mathrm{~g}$ ABTS (2,2'-azino-bis 3-ethylbenzothiazoline-6-sulphonic acid) $(\mathrm{M}=$ $548.7 \mathrm{~g} \mathrm{~mol}^{-1}$ ) was placed into a dark-color bottle and supplemented with $2 \mathrm{~mL} 12.25 \mathrm{mM}$ potassium persulphate solution. The final volume was completed to $10 \mathrm{~mL}$ with $\mathrm{ddH}_{2} \mathrm{O}$, kept at room temperature for $12-16$ hours and preserved in a fridge at $+4{ }^{\circ} \mathrm{C}$, then used in analysis. The life span of this solution is only two days. PBS (Phosphate Buffered Saline) solution; for $1.8 \mathrm{mM}$ monopotassium phosphate $\left(\mathrm{KH}_{2} \mathrm{PO}_{4}\right)\left(\mathrm{M}=136.08 \mathrm{~g} \mathrm{~mol}^{-1}\right), 0.24 \mathrm{~g} \mathrm{KH}_{2} \mathrm{PO}_{4}$ was dissolved in $500 \mathrm{~mL} \mathrm{ddH}_{2} \mathrm{O}$ and supplemented with $8 \mathrm{~g} \mathrm{NaCl}$ to get $137 \mathrm{mM}$ sodium chlorine $(\mathrm{NaCl})\left(\mathrm{M}=58.44 \mathrm{~g} \mathrm{~mol}^{-1}\right)$, 
supplemented then with $0.2 \mathrm{~g} \mathrm{KCl}$ to get $2.7 \mathrm{mM}$ potassium chlorine $(\mathrm{KCl})\left(\mathrm{M}=74.55 \mathrm{~g} \mathrm{~mol}^{-1}\right)$ and finally supplemented with $1.4 \mathrm{~g} \mathrm{Na}_{2} \mathrm{HPO}_{4}$ to get $10 \mathrm{mM}$ disodium phosphate $\left(\mathrm{Na}_{2} \mathrm{HPO}_{4}\right)\left(\mathrm{M}=141.96 \mathrm{~g} \mathrm{~mol}^{-1}\right)$. Final value of the solution was completed to 1 liter. Solution $\mathrm{pH}$ was adjusted to 7.4 with $0.1 \mathrm{M} \mathrm{HCl}$. The solution was autoclaved at $121^{\circ} \mathrm{C}$ and $1 \mathrm{~atm}$ pressure for 20 minutes and preserved under room conditions. For dilution of ABTS radical solution with PBS, Analytik Jena Specord 200 (Analytik Jena, Germany) model spectrophotometer was set as $734 \mathrm{~nm}$ wave length and $1 \mathrm{~mL}$ ABTS was mixed with sufficient quantity of PBS as to read $700 \mathrm{~nm}( \pm 1)$ in spectrophotometer. This absorbance was used in antioxidant activity measurements of the samples.

Sample dilution and measurement: Spectrophotometer was initially set to zero against air, then against PBS, $990 \mu \mathrm{L}$ absorbent was taken and the value assumed to be minute-zero $(700 \pm 1 \mathrm{~nm})$ was read. The cuvette was removed from the device and $10 \mu \mathrm{L}$ fruit sample which was taken from $20{ }^{\circ} \mathrm{C}$ before 10 minutes, thawed at room temperature and mixed in vortex tube mixer, was added to available absorbent $(990 \mu \mathrm{L})$, waited for 6 minutes and a new reading was performed in spectrophotometer. Since the \% inhibition ratio of this initial measurement value should not exceed $35 \%$, $10 \mu \mathrm{L}$ samples was taken into another Eppendorf tube and diluted with $\mathrm{ddH}_{2} \mathrm{O}$ at 1/2,1/3, 1/5 or 1/10 ratios. Diluted fruit sample $(10 \mu \mathrm{L})$ was again mixed with $990 \mu \mathrm{L}$ absorbent and reading was renewed. Following the reduction of inhibition below $35 \%, 20 \mu \mathrm{L}$ and $30 \mu \mathrm{L}$ diluted samples were added to $980 \mu \mathrm{L}$ and $970 \mu \mathrm{L}$ absorbents to complete the sample volume of the cuvettes to $1000 \mu \mathrm{L}$ and 3 measurements were performed. The \% inhibition ratio of the samples was calculated with the aid of the following equation:

$$
\% \text { Inhibition }=\left\{\frac{\text { Spectrophotometer reading at minute } 0-\text { reading at } 6 \text { th minute }}{\text { reading at minute } 0}\right\} \times 100
$$

Before the analyses, $2.5 \mathrm{mM}$ Trolox stock solution was taken into 4 flasks in 2, 4, 6 and $8 \mathrm{~mL}$ and the flasks were then completed to final volume with PBS solution to get standard solutions. From these solutions, $10 \mu \mathrm{L}$ was taken and added to $1 \mathrm{~mL}$ radical solutions in micro cuvettes to prepare Trolox-containing solutions at 5, 10, 15 and $20 \mu \mathrm{mol}$ concentrations. The spectrophotometric treatments applied to the samples (6-hydroxy-2, 5, 7, 8-tetramethylchroman-2carboxylic acid) were also applied to Trolox standards, mean inhibition values were calculated and graphed against Trolox concentrations. Linear regression analysis was applied to resultant data to get Trolox standard curve and the equation defining this curve (Figure 1). Results were expressed as TEAC value. This value was obtained as the ratio of the slope of sample percent inhibition curve to the slope of Trolox standard curve. Resultant slope value was multiplied by dilution factor to get antioxidant activity of the samples (Tahmaz \& Söylemezoğlu 2017). Results were expressed in $\mu$ mol TE $\mathrm{g} \mathrm{fw}^{-1}\left(\mu \mathrm{mol} \mathrm{TE} \mathrm{g} \mathrm{fw}^{-1}\right)$ for both fruit flesh and fruit flesh + skin tissue.

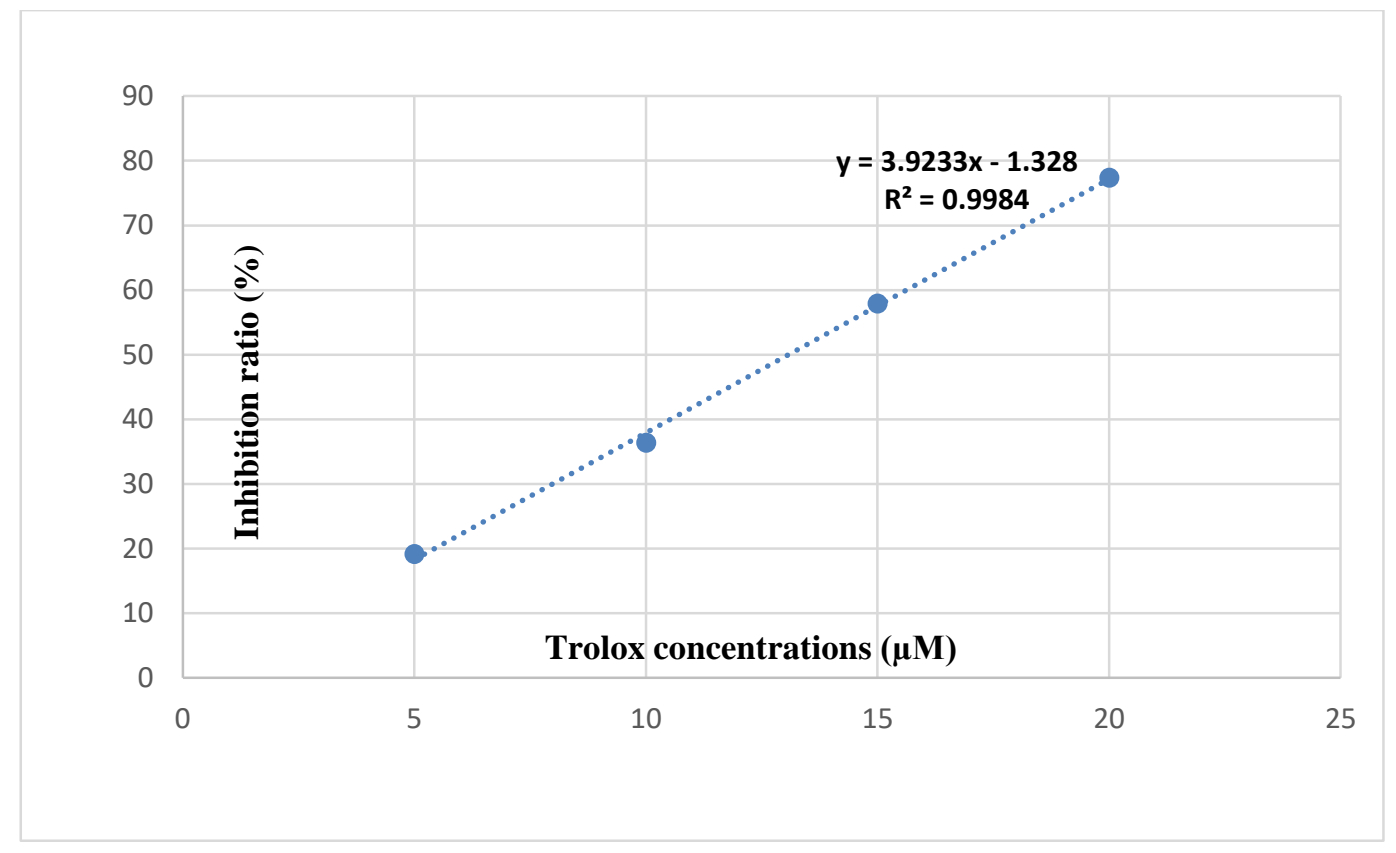

Figure 1- Trolox standard curve 
Total phenolics: Total phenolics were determined in accordance with Folin-Ciocalteu method (Singleton \& Rossi 1965). Samples were thawed at room temperature, mixed in a vortex tube mixer and placed into Eppendorf tubes. Then, $100 \mu \mathrm{L}$ sample was taken and placed into $10 \mathrm{~mL}$ flasks, supplemented with $8.4 \mathrm{~mL}$ distilled water and $500 \mu \mathrm{L}$ folin $(1 \mathrm{~L}=1.24 \mathrm{~kg})$ and the flask was intermittently shaken in hand during 3 minutes of waiting period. Resultant mixture was supplemented with $1000 \mu \mathrm{L} 20 \%$ sodium carbonate $\left(\mathrm{Na}_{2} \mathrm{CO}_{3}\right)$ solution (for $20 \% 250 \mathrm{~mL} \mathrm{Na} \mathrm{CO}_{3}$ solution, $50 \mathrm{~g}$ $\left.\mathrm{Na}_{2} \mathrm{CO}_{3}\left(\mathrm{M}=105.99 \mathrm{~g} \mathrm{~mol}^{-1}\right)\right)$ was dissolved in distilled water. The mixture was then instantly kept at dark conditions for 1 hour. Blanks were prepared before spectrophotometric readings of the samples. For blanks, distilled water was used instead of fruit juice. As defined above, mixture of $100 \mu \mathrm{L}$ distilled water $+8.4 \mathrm{~mL}$ distilled water $+500 \mu \mathrm{L}$ folin were mixed for 3 minutes, kept at room temperature, supplemented with $1000 \mu \mathrm{L} \mathrm{Na} \mathrm{CO}_{3}$ and kept at dark instantly for 1 hour. Before reading, $5 \mathrm{~mL}$ blank mixture was drawn into syringe, filtered through 0.45 micronic filter and $2 \mathrm{~mL}$ filtrate was placed into the cuvette. Spectrophotometer was set to zero against air, then set to $765 \mathrm{~nm}$ wave length. The cuvette with blank mixture was placed into the device and reading was performed. Then the cuvette with $2 \mathrm{~mL}$ of sample was placed into the device and reading was performed. The cuvette with blank mixture was placed into the device after each sample reading to make the device ready for the subsequent sample readings.

For calculations, gallic acid solutions were prepared at different concentrations 50, 100, 150, 250, 500 and $750 \mathrm{mg} \mathrm{L}^{-1}$ $\left(\mathrm{R}^{2}=0.9999\right)$. The spectrophotometric treatments were applied to gallic acid standards and then absorbance values were calculated according to gallic acid concentrations. Linear regression analysis was applied to data to get gallic acid standard curve and the equation defining this curve (Figure 2 ). The $\mathrm{R}^{2}$ equation best fitting to sample concentrations was selected and each reading was calculated with the appropriate equation to improve the accuracy of the results. The value obtained from the equations of the standard curves was multiplied by a dilution factor. Results were expressed in mg GAE kg fw${ }^{-1}$ for both fruit flesh and fruit flesh + skin tissue (Tahmaz \& Söylemezoğlu 2017).

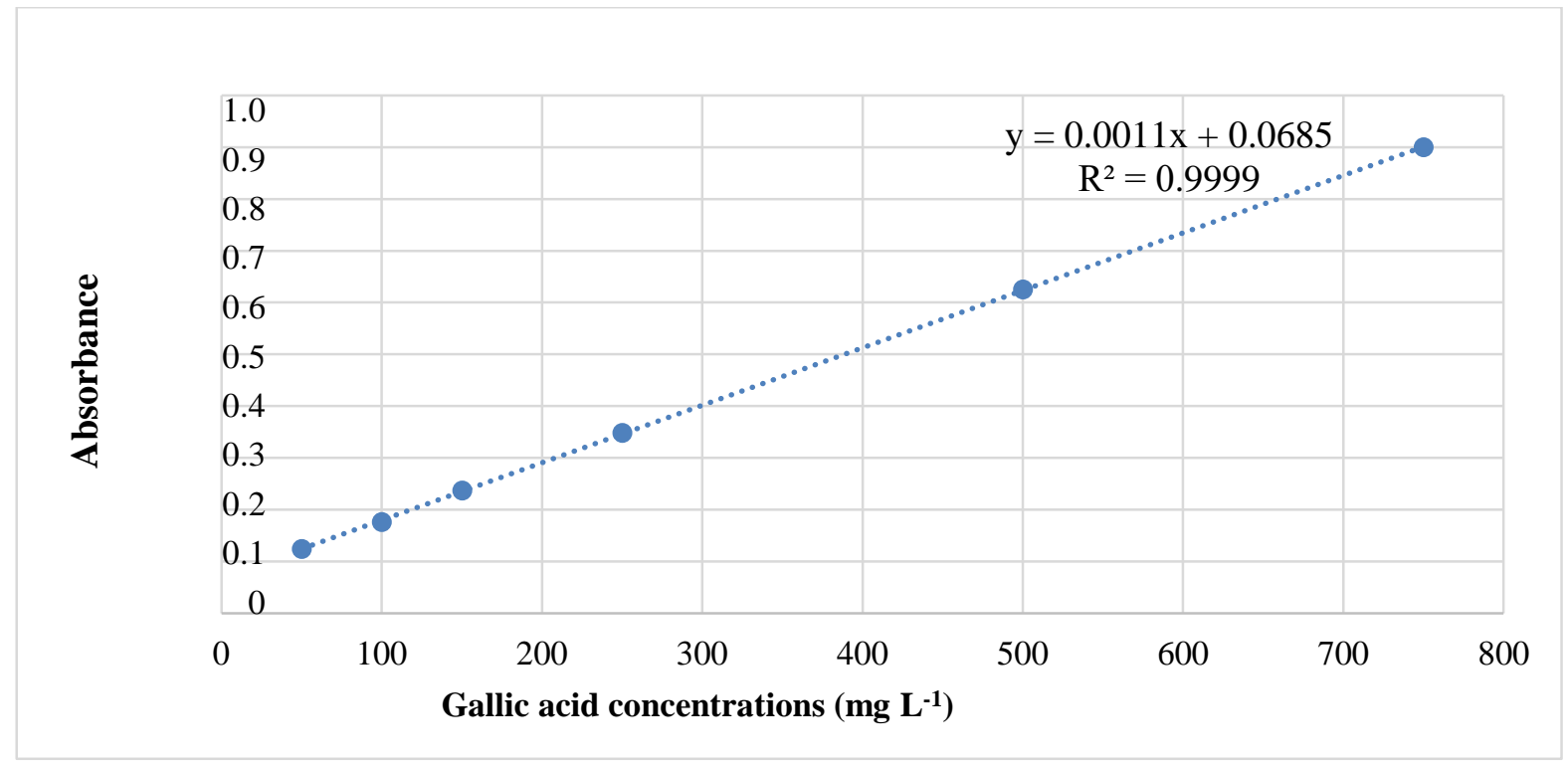

\section{Figure 2- Gallic acid standard curve}

Each experiment was conducted in randomized plots design with 3 replications. Experimental data were subjected to variance analysis and $F$-test $(\mathrm{P} \leq 0.05)$ with Minitab software (MINITAB Inc. version 17). Significant means were compared with Duncan's multiple range test at $5 \%$ significance level.

\section{Results and Discussion}

The differences in antioxidant activity and total phenolics in fruit flesh and fruit flesh + skin tissue of the cultivars was found to be significantly different $(\mathrm{P} \leq 0.001)$ (Table 1$)$. 
Table 1- Antioxidant activity and total phenolics in fruit tissues of the local and standard apple cultivars

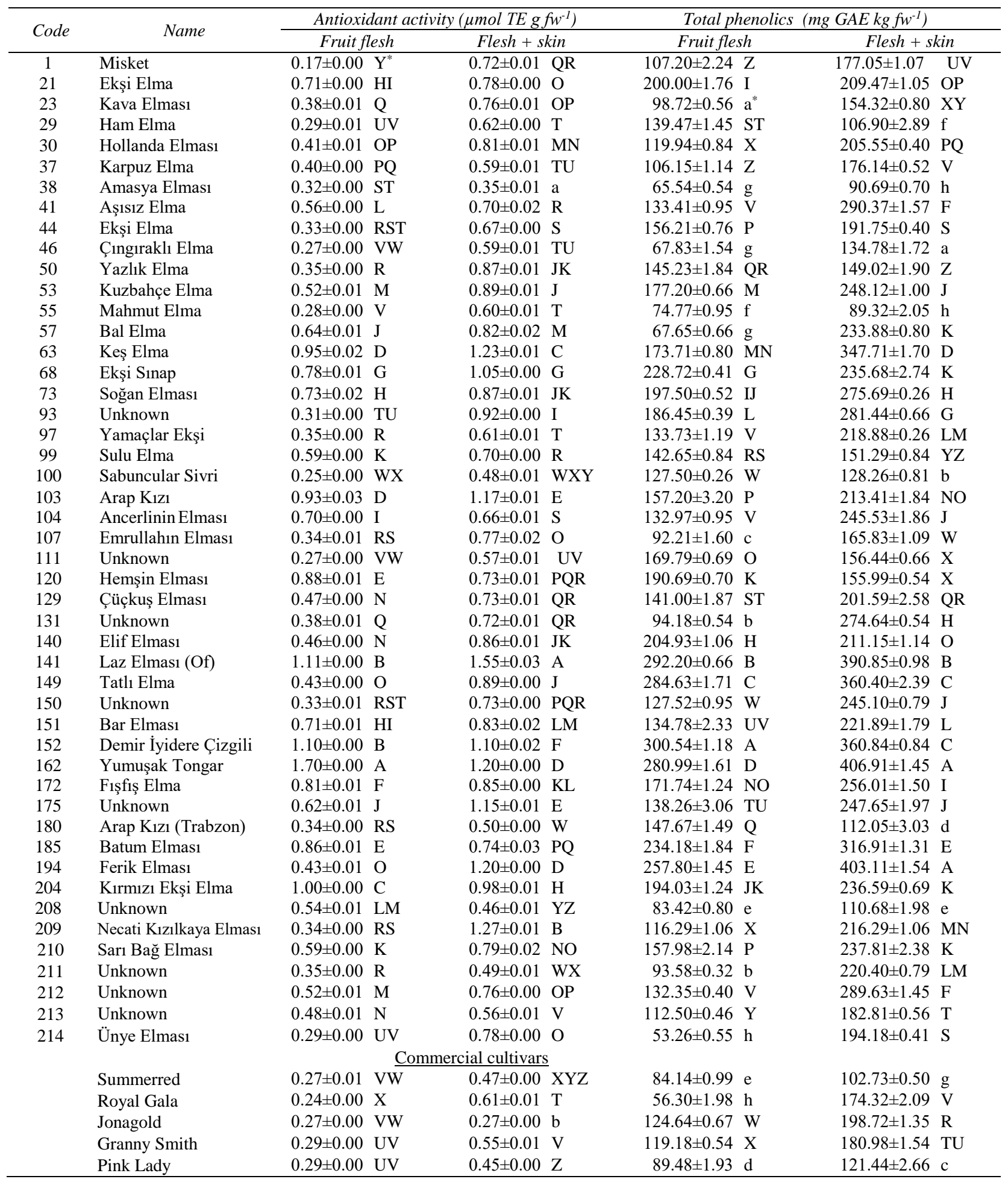

", Significant differences were indicated with capital letters (“A”...), then small letters (“a”...) after "Z”. Mean separation within columns followed by the same letter are not significantly different at $\mathrm{P} \leq 0.05$ by Duncan's multiple range test

Antioxidant activities of majority of local apple cultivars were 1.2-4.2 times greater in flesh + skin than in flesh. Total phenolics were 1.2-3.6 times greater in flesh + skin than in flesh (Table 1). In previous studies comparing fruit 
skin and fruit flesh, antioxidant activity of fruit skin was reported as 1.5-9.2 times greater than the fruit flesh and total phenolics of fruit skin was reported as 1.2-6.0 times greater than the fruit flesh (Özgen \& Tokbaş 2007; Drogoudi et al 2008; Yuri et al 2009; Vieira et al 2011; Wang et al 2015). Present findings for majority of local apple cultivars comply with those earlier ones. However, antioxidant activity of 6 local cultivars $(104,120,162,185,204,208)$ was greater in fruit flesh compared with flesh + skin tissue and antioxidant activity of 4 local cultivars $(21,38,152,172)$ in flesh + skin was close or equal to antioxidant activity of fruit flesh. Total phenolics of 4 genotypes $(29,111,120,180)$ were greater in fruit flesh than in flesh + skin and total phenolics of 5 local cultivars $(21,50,68,99,100)$ in flesh + skin was close or equal to total phenolics of fruit flesh. However, it was reported in literature that apple fruit flesh generally had lower antioxidant activity and total phenolics than the whole fruit with fruit skin or only fruit skin tissues. Present findings were different from those earlier reports since several local cultivars were included in this study and there were quite high genetic diversity among these cultivars, thus, such a diversity might have resulted in having unexpected antioxidant activity and total phenolics for these cultivars. Especially the local cultivar 120 was quite remarkable with its greater antioxidant activity and total phenolics in fruit flesh than in flesh + skin tissue. In majority of local cultivars, antioxidant activity and total phenolics of fruit flesh and flesh + skin tissues had greater than the values of standard cultivars (Table 1). As compared to the standard cultivars, $87.5 \%$ of local cultivars had greater antioxidant activity in fruit flesh and $77.1 \%$ had greater antioxidant activity in fruit flesh + skin tissue. The local cultivar 'Yumuşak Tongar' had a greater antioxidant activity in flesh compared with flesh + skin, while its antioxidant activity in flesh was higher 6 times in average compared with those from commercial cultivars. The local cultivars of 141, 152 and 204 had 3.4-4.2 times greater antioxidant activity in fruit flesh than the standard cultivars. In fruit flesh + skin tissue, the local cultivars of 63, 141, 162 and 209 had 2-6 times greater antioxidant activity than the standard cultivars. Again, as compared to the standard cultivars, $68.8 \%$ of local cultivars had greater total phenolics in fruit flesh and $60.4 \%$ had greater total phenolics in fruit flesh + skin tissue. The local cultivars of 152, 141, 149 and 162 had 2-5 times greater total phenolics in fruit flesh than the standard cultivars. In fruit flesh + skin tissue, the local cultivars of 162, 194, 141 and 149 had 2-4 times greater total phenolics than the standard cultivars. As $\mu \mathrm{mol} \mathrm{TE} \mathrm{g} \mathrm{fw}^{-1}$, antioxidant activity in fruit flesh of local cultivars varied between 0.17 (cultivar 1) and 1.70 (cultivar 162) and antioxidant activity in fruit flesh of standard cultivars varied between 0.24 ('Royal Gala') and 0.29 ('Pink Lady' and 'Granny Smith'); antioxidant activity in flesh + skin tissue of local cultivars varied between 0.35 (cultivar 38) and 1.55 (cultivar 141) and antioxidant activity in flesh + skin tissue of standard cultivars varied between 0.27 ('Jonagold') and 0.61 ('Royal Gala'). As mg GAE kg fw'-1, total phenolics in fruit flesh of local cultivars varied between 53.26 (cultivar 214) and 300.54 (cultivar 152) and total phenolics in fruit flesh of standard cultivars varied between 56.30 ('Royal Gala') and 124.64 ('Jonagold'); total phenolics in flesh + skin tissue of local cultivars varied between 89.32 (cultivar 55) and 406.91 (cultivar 162) and total phenolics in flesh + skin tissue of standard cultivars varied between 102.73 ('Summerred') and 198.72 ('Jonagold'). Present findings for 'Jonagold' apple cultivar partially comply with the findings of Lachman et al (2006). Although researchers reported quite greater total phenolics for Jonagold apples than the present values $\left(1216.43 \pm 12.64 \mathrm{mg} \mathrm{kg} \mathrm{fw}^{-}\right.$ ${ }^{1}$ ), complying with the present findings, they reported greater total phenolics for 'Jonagold' apples than for the other standard cultivars. In present study, the local cultivars of 141, 152 and 162 had high antioxidant activity and total phenolics both in fruit flesh and flesh + skin tissue. There are great differences in antioxidant activity and total phenolics of the apple cultivars in different studies since different methods were employed in analyses. Albayrak et al (2010) classified the methods used for antioxidants of the plants in two groups as of electron transfer (ET)-based and hydrogen atom transfer (HAT) reactions-based methods. Özgen \& Tokbaş (2007) used TEAC method and reported antioxidant capacity of 'Amasya' apple as $19.8 \mu \mathrm{mol} \mathrm{TE} \mathrm{g} \mathrm{fw}^{-1}$ in skin and as $5.0 \mu \mathrm{mol} \mathrm{TE} \mathrm{g} \mathrm{fw}^{-1}$ in fruit flesh. Vieira et al (2011) investigated antioxidant capacity of 11 Brazilian apple cultivars with TEAC method and reported antioxidant activities of the apple cultivars varied as between 3.8 ('Golden Delicious') and 9.6 ('Epagri- $\mathrm{F}_{5} \mathrm{P}_{283}$ ') $\mu \mathrm{mol} \mathrm{TEAC} \mathrm{g}$ fw $^{-1}$ in fruit flesh and as between 12.25 ('Golden Delicious') and 41.4 ('Catarina') $\mu$ mol TEAC $\mathrm{g} \mathrm{fw}^{-1}$ in fruit skin. Wang et

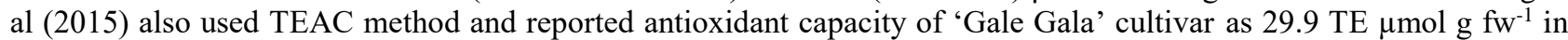
fruit skin and as $3.6 \mathrm{TE} \mu \mathrm{mol} \mathrm{g} \mathrm{fw}{ }^{-1}$ in fruit flesh. Although the same method was employed, those reports of the previous researchers were both different from each other and different from the present ones. Such differences were mainly attributed to differences in genotypes and dilution procedures used in preparation of the samples. A similar case is also valid for total phenolics. Present findings on total phenolics comply with the findings of Markowski et al (2007) reporting average total phenolics of 'Champion', 'Jonagold', 'Idared' and 'Topaz' apple cultivars as $821 \mathrm{mg} \mathrm{kg}^{-1}$, findings of Kevers et al (2011) reporting total phenolics in whole fruit of 'Gala' apple cultivar as $2250 \mathrm{mg} \mathrm{GAE} \mathrm{kg} \mathrm{fw}{ }^{-1}$, findings of Wang et al (2015) reporting total phenolics of 'Gale Gala' apple cultivar as $1641.8 \mathrm{mg} \mathrm{kg} \mathrm{fw}^{-1}$ in skin tissue and as $160.3 \mathrm{mg} \mathrm{kg} \mathrm{fw}^{-1}$ in fruit flesh. Such differences between the total phenolics of the previous studies and differences from the present ones again mainly resulted from the differences in dilution procedures. 
Present findings revealed a great variation in antioxidant activity and total phenolics of high-table value local apple cultivars encountered along the coastal zones of Northeaster Anatolia Region of Turkey. Majority of local cultivars had greater antioxidant activity and total phenolics both in fruit flesh and flesh + skin tissue than the standard cultivars. With regard to these parameters of the local cultivars, the ones with greater values in fruit flesh than in flesh + skin tissue were remarkable. Further research is recommended to determine the other biochemical characteristics of the local cultivars prominent with their antioxidant activity and total phenolics.

\section{Conclusions}

Present study revealed a great variation in antioxidant activity and total phenolics of local apple cultivars encountered along the coastal zones of Northeaster Anatolia Region of Turkey. Majority of local cultivars had greater antioxidant activity and total phenolics in both flesh and flesh + skin tissues compared with commercial cultivars. With regard to these parameters of the local cultivars, the ones with greater values in flesh than in flesh + skin tissues were remarkable. Further research is needed to determine the other biochemical characteristics of the local cultivars prominent with their antioxidant activity and total phenolics. Recognizing the potential antioxidants in local cultivars enables researchers to use these unique genetic materials in national apple breeding programs.

\section{References}

Albayrak S, Sağdıç O \& Aksoy A (2010). The assays used for assessing antioxidant capacities of herbal products and foods. Erciyes University Journal of Institute of Science and Technology 26(4): 401-409

Balasundram N, Sundram K \& Samman S (2006). Phenolic compounds in plants and agri-industrial by-products: Antioxidant activity, occurrence, and potential uses. Food Chemistry 99: 191-203

Bohm V, Kschonsek J, Wolfram T \& Stöckl A (2018). Polyphenolic compounds analysis of old and new apple cultivars and contribution of polyphenolic profile to the in vitro antioxidant capacity. Antioxidants (Basel) 7(1): 1-14

Drogoudi P D, Michailidis Z \& Pantelidis G (2008). Peel and flesh antioxidant content and harvest quality characteristics of seven apple cultivars. Scientia Horticulturae 115: 149-153

Garcia O B, Castillo J, Marin F R, Ortuno A \& Del Rio J A (1997). Uses and properties of Citrus flavonoids. Journal of Agricultural and Food Chemistry 45: 4505-4515

Imeh U \& Khokhar S (2002). Distribution of conjugated and free phenols in fruits: antioxidant activity and cultivar variations. Journal of Agricultural and Food Chemistry_50(22): 6301-6306

Kevers C, Pincemail J, Tabart J, Defraigne J O \& Dommes J (2011). Influence of cultivar, harvest time, storageconditions, andpeeling on the antioxidant capacity and phenolic and ascorbic acid contents of apples and pears. Journal of Agricultural and Food Chemistry 59: 6165-6171

Khanizadech S, Tsao R, Rekika D, Yang R, Charles M T \& Rupasinghe H P V (2008). Polyphenol composition and total antioxidant capacity of selected apple genotypes for processing. Journal of Food Composition and Analysis 21: 396-401

Lachman J, Sulc M, Sus J \& Pavlikova O (2006). Polyphenol content and antiradical activity in different apple varieties. Horticultural Science (Prague) 33(3): 95-102

Lee K W, Kim Y J, Kim D, Lee H J \& Lee C Y (2003). Major phenolics in apple and their contribution to the total antioxidant capacity. Journal of Agricultural and Food Chemistry 51: 6516-6520

Manach C, Mazur A \& Scalbert A (2005). Polyphenols and prevention of cardiovascular diseases. Current Opinions in Lipidology 16: $77-84$

Margaret E, Shailaja A M \& Rao V V (2015). Evaluation of antioxidant activity in different parts of Syzygium cumini (Linn.). International Journal of Current Microbiology and Applied Sciences 4(9): 372-379

Markowski J, Plocharski W \& Mieszczakowska M (2007). Effect of cultivar and processing on phenolics and antioxidant activity of apple products. Acta Horticulturae 744: 363-367 
Middleton E, Kandaswami C \& Theoharides T C (2000). The effects of plant flavonoids on mammalian cells: implications for inflammation, heart disease, and cancer. Pharmacological Reviews 52: 673-751

Özgen M \& Tokbaş H (2007). Effect of sun exposure and fruit tissues on antioxidant capacity of Amasya and Fuji apple cultivars. Journal of Agricultural Faculty of Gaziosmanpasa University, JAFAG 24(2): 1-5

Re R, Pellegrini N, Proteggente A, Pannala A, Yang M \& Rice-Evans C (1999). Antioxidant activity applying an improved ABTS radical cation decolorization assay. Biology and Medicine 26: 1231-1237

Rice-Evans C A, Miller N J, Bolwell P G, Bramley P M \& Pridham J B (1995). The relative antioxidant activities of plant-derived polyphenolic flavonoids. Free Radical Research 22(4): 375-383

Singleton V L \& Rossi J A (1965). Colorimetric of total phenolics with phosphomolybdic-phosphotungstic acid reagents. American Journal of Enology and Viticulture 16: 144-158

Stratil P, Klejdus B \& Kuban V (2007). Determination of phenolic compounds and their antioxidant activity in fruits and cereals. Talanta 21: 1741-1751

Szajdek A \& Borowska E J (2008). Bioactive compounds and health-promoting properties of berry fruits: a review. Plant Foods and Human Nutrition 63: 147-156

Tahmaz H \& Söylemzoğlu G (2017). Effects of vinification techniques combined with UV-C irradiation on phenolic contents of red wines. Journal of Food Science 82(6): 1351-1356

Tsao R, Yang R, Xie S, Sockovie S \& Khanizadeh S (2005). Which polyphenolic compounds contribute to the total antioxidant activities of apple? Journal of Agricultural and Food Chemistry 53: 4989-4995

Veberic R, Trobec M, Herbinger K, Hofer M, Gill D \& Stampar F (2005). Phenolic compounds in some apple (Malus domestica Borkh) cultivars of organic and integated production. Journal of the Science of Food and Agriculture 85: 1687-1694

Vieira F G K, Borges G S C, Copetti C, Pietro P F D, Nunes E C \& Fett R (2011). Phenolic compounds and antioxidant activity of the apple flesh and peel of eleven cultivars grown in Brazil. Scientia Horticulturae 128: 261-266

Vinson J A, Su X, Zubik L \& Bose P (2001). Phenol antioxidant quantity and quality in foods: fruits. Journal of Agricultural and Food Chemistry 49: 5315-5321

Vrhovsek U, Rigo A, Tonon D \& Mattivi F (2004). Quantitation of polyphenols in different apple varieties. Journal of Agricultural and Food Chemistry 52: 6532-6538

Wang X, Li C, Liang D, Zou Y, Li P \& Ma F (2015). Phenolic compounds and antioxidant activity in red-fleshed apples. Journal of Functional Foods 18: 1086-1094

Wolfe K, Wu X \& Liu R H (2003). Antioxidant activity of apple peels. Journal of Agricultural and Food Chemistry 51: 609-614

Yuri J A, Neira A, Quilodran A, Motomura Y \& Palomo I (2009). Antioxidant activity and total phenolics concentration in apple peel and flesh is determined by cultivar and agroclimatic growing regions in Chile. Journal of Food, Agriculture and Environment 7(3-4): 513-517 